\title{
Complex Formation Between Iron(III) and Isonicotinohydroxamic Acid and Its Microbial Studies
}

\author{
${ }^{* 1}$ A.O. Aliyu and ${ }^{2}$ J.N. Nwabueze \\ *Department of Chemistry, Nigerian Defence Academy, PMB 2109, Kaduna. \\ Department of Chemistry, University of Abuja, PMB 117, FCT,Abuja, Nigeria. \\ [*Correspondence Address: e-mail:salimatadetutu@yahoo.com]
}

\begin{abstract}
Complex of Fe(III) with isonicotinohydroxamic acid (INHA) has been investigated by using spectrophotometric method. $\mathrm{Fe}$ (III) in aqueous solution revealed the sole formation of the 1:3 complexes at equilibrium. The spectra and magnetic studies of the isolated complex indicated octahedral coordination. The bonding mode proposed for the Fe(III) hydroxamate complex is N-bonding mode.The complex is biologically active against Staphyloccus.aureus, Escherichia-coli, Salmonella-typhyllium, Klebsiella , $\alpha$-heamolytic Streptocococcus, Pseudomonias, Corrynebacterium and Neisseria.
\end{abstract}

KEYWORDS: Hydroxamic acid, Fe(III) complex, N-bonding mode, microorganism and octahedral coordination.

\section{INTRODUCTION}

Hydroxamic acids having one or more$\mathrm{CONHOH}-$ groups have been extensively studied as a consequence of their biological importance which is related with their ability to form metal ion complexes (Fernandes et al., 1997). Hydroxamic acids and other compounds containing the hydroxamate group are ubiquitous in nature and are intimately associated with iron transport in bacteria (Nwabueze 1997). Iron(III) complexes of naturally occurring hydroxamate acids called siderophores, are involved in the processes of iron transport from the environment into the living organisms (Nigovic et al., 2002).

Naturally occurring hydroxamic acids such as desferrioxamine $\mathrm{B}$, have typically three bidentate binding sites, making them hexadentate ligands. However, a small group of these compounds have only two hydroxamate binding sites. The most well-known example is rhodotorulic acid which forms a highly stable $\mathrm{Fe}$ (III) complex between pH 3 and 12 (Biruset al., 1998).

Monohydroxamic acids (such as acetohydroxamic acids $\mathrm{CH}_{3} \mathrm{CONHOH}=$ Aha) after deprotonation act as bidentate ligands forming octahedral complexes with a series of metal ions via coordination through the two oxygen atoms of the CONHO - group. This type of co-ordination has been observed for complexes formed with $\mathrm{Fe}^{\mathrm{III}}$, $\mathrm{Cr}^{\mathrm{III}}, \mathrm{Ni}^{\mathrm{II}}, \mathrm{Co}^{\mathrm{II}}$ and $\mathrm{Zn}^{\mathrm{II}}$ ions, which exhibited octahedral configuration both in the solid state and in solution (Kurzak et al.,1992).This was confirmed by x-ray diffraction studies carried out on complexes of tris (benzohydroxamic acid) with $\mathrm{Fe}$ (III) dihydrate and tris (benzohydroxamic acid) with chromium(III) (Brown et al., 1979).

They are known to have antibacterial and antifungal properties and are inhibitors of enzymes such as prostaglandin $\mathrm{H}$ synthase, peroxidases, urease, and matrix metalloproteinases (MMP) which degrade the barriers holding cells in place and are involved in tumor growth. Their ability to inhibit enzymes make them ideal as drug candidates e.g Marimastat is a hydroxamic acid which is an MMP inhibitor and is at an advantage of clinical development as an anticancer drug (Celine 1972).

The biological activity of hydroxamic acids appeared to be related to their iron-chelating ability. The different but related, problems of iron-deficiency anaemia and iron overload resulting from the treatment of thalassaemia (Bates et al., 1972 and Dobbin and Hider 1990).are still serious, especially in tropical countries. There is therefore, a continuous search for iron complexes which can act as suitable oral sources to counter iron deficiency and suitable ligands with high affinities for iron to relieve overload.

While there are reports of studies involving iron complexes of some monohydroxamic acids, nothing is known about those derived from isonicotinohydroxamic acids despite report that 
other derivatives of these acids are bioactive (Nwabueze, 1996). However, complexes of isonicotinohydroxamic acid with $\mathrm{Ni}(\mathrm{II}), \mathrm{Co}(\mathrm{II})$ and $\mathrm{VO}^{\mathrm{IV}}$ have been reported (Nwabueze and Aliyu,2007; Aliyu and Nwabueze ,2008,Aliyu and Nwabueze 2009;).

This paper is therefore a report on the work carried out on the synthesis, characterization and study of the interaction of iron(III) in aqueous solution with hydroxamic acid with special emphasis on the structure and bonding involved. In addition, some physico-chemical properties and the microbial activity of the complex is investigated and included in this report.

\section{EXPERIMENTAL}

Ethylisonicotinate was obtained from Aldrich.UK All other reagents were of AnalaR-grade. $\mathrm{NaNO}_{3}$ was used for the preparation of the background electrolyte and stock solutions. Water was doubly distilled, degassed using purified $\mathrm{N}_{2}$ and stored in glass stoppered flasks. $\mathrm{KOH}$ and $\mathrm{HNO}_{3}$ used for adjusting $\mathrm{pH}$ were stored in glass ampoules and were standardized with potassium hydrogen phthalate and tris (hydroxymethyl) methyl with amine respectively. The $\mathrm{pH}$ measurements were made using a radiometer Copenhangen Research $\mathrm{pH}$ meter calibrated with standard buffer tables (2, 4 and 9).

Electronic spectra were recorded on ATI Maltson Genesis series. FT-IR ${ }^{\mathrm{TM}}$ machine as Nujol mull in the $4000-200 \mathrm{~cm}^{-1}$ spectra region. Room temperature magnetic susceptibility measurements were made on MSB Auto magnetic susceptibility balance.

\section{Preparation of the ligands}

Isonicotinohydroxamic acid (INHA) was prepared as described by Jones and Scott (1922)

The various stages involved in the preparation of NHA are as represented by the following reactions :

$2 \mathrm{Na}+2 \mathrm{MeOH} \rightarrow 2 \mathrm{MeONa}+\mathrm{H}_{2}$

$\mathrm{NH}_{2} \mathrm{OH} . \mathrm{HCI}+\mathrm{MeONa} \rightarrow \mathrm{NH}_{2} \mathrm{OH}+\mathrm{NaCl}$

$\mathrm{MeOH}$

$\mathrm{NH}_{2} \mathrm{OH}+\mathrm{RCO}_{2} \mathrm{Et} \rightarrow \mathrm{RCON}(\mathrm{H}) \mathrm{OH}+\mathrm{EtOH}$ $\mathrm{RCON}(\mathrm{H}) \mathrm{OH}+\mathrm{MeONa} \rightarrow \mathrm{RCON}\left(\mathrm{H}^{-} \mathrm{O}^{-} \mathrm{Na}^{+}+\right.$ $\mathrm{MeOH}$

$\mathrm{RCON}(\mathrm{H}) \mathrm{O}^{-}-\mathrm{Na}^{+}+\mathrm{HCl} \rightarrow \mathrm{RCON}(\mathrm{H}) \mathrm{OH}+$ $\mathrm{NaCl}$ where $\mathrm{R}=$ Pyridine ring for the complex of INHA model.

Preparation of the complex $\left(\mathrm{Fe}(\mathrm{INHA})_{3} \mathbf{2 H}_{2} \mathrm{O}\right)$ $\mathrm{Fe}\left(\mathrm{NO}_{3}\right)_{3} .9 \mathrm{H}_{2} \mathrm{O} \quad(0.8080 \mathrm{~g}, 0.002 \mathrm{~mol})$ in cold water was added with stirring to a solution of INHA $(0.843 \mathrm{~g}, 0.006 \mathrm{~mol})$ in water $\left(20 \mathrm{~cm}^{3}\right)$. To the resulting purple solution, a $10 \%$ solution of $\mathrm{NaHCO}_{3}$ was added dropwise until precipitation occurred. The dark red precipitate was removed by filtration, washed with small aliquots of $\mathrm{Et}_{2} \mathrm{O}$ and dried over silica gel in a vacuum desiccator. Yield was 58\%.

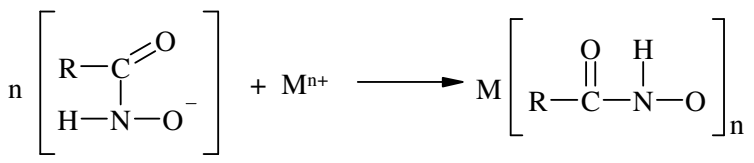

Where $\mathrm{n}=$ the number of moles of a neutral monodentate ligand.

\section{Equilibrium Studies}

The $\mathrm{pKa}$ value for the ligand was determined spectrophotometrically by the method of Albert and Sergent (1971) using boric acid and borax of ionic strength $0.1 \mathrm{~mol} \mathrm{dm}^{-3}$ and $0.025 \mathrm{~mol} \mathrm{dm}^{-3}$ as buffer for INHA ligand. In each case, the ligand stock solution was $5.0 \times 10^{-4} \mathrm{~mol} \mathrm{dm}^{-3}$ diluted five folds in the buffer solution for INHA. Measurements were made in eight boric/borax buffer solutions at $215 \mathrm{~nm}$ on a Unicam SP800 spectrophotometer. The number of complexes present in solution at equilibrium was determined by the isosbestic point method and graphical Matrix rank analysis using nine solution containing 1:1 - 1:5 metal: ligand ratio ( ligand concentration increasing in unit of 0.5 ). Fifteen solutions containing 1:1 - 1:5 metal: ligand ratios and $\mathrm{pH}$ values between 1 and about 3 were used to generate the absorbance data. A solution of $I=$ $0.1 \mathrm{~mol} \mathrm{dm}^{-3}$ made up of $0.01 \mathrm{~mol} \mathrm{dm}^{-3} \mathrm{HNO}_{3}$ and $0.09 \mathrm{~mol} \mathrm{dm}^{-3} \mathrm{NaNO}_{3}$ was used to prepare equimolar stock solution of $\mathrm{Fe}^{3+}$ and the ligand of $2.5 \times 10^{-3} \mathrm{~mol} \mathrm{dm}^{-3}$. The same solution was used for all dilutions. Solutions of 0.01 and $0.1 \mathrm{~mol}$ $\mathrm{dm}^{-3}$ of $\mathrm{NaOH}$ and $\mathrm{HNO}_{3}$ respectively, were used to adjust the $\mathrm{pH}$ of the reaction mixture. In all case, the solution were thermostated at $25^{\circ} \mathrm{C}$ for $2 \mathrm{hrs}$ in ultrasonic bath.

\section{Evaluation of the antimicrobial activity}

The antimicrobiall activity of the test compound was assayed against four Gram +ve bacteria 
(Staphyloccus aureus, Salmonella typhyllium, $\alpha$ heamolytic Streptocococcus and Corryne bacterium) and four Gram -ve bacteria (Escherichia coli, Klebsiella, Pseudomonias and Neisseria). All are regarded as pathogenic to humans and animals. All media and bacteria suspensions were prepared using a method adapted from that of Cruickshank (1965).

About $15-20 \mathrm{~cm}^{3}$ of molten nutrient agar was poured into a $10 \mathrm{~cm}$ diameter sterile Petri plates. After solidification of the agar, three cups $(10 \mathrm{~mm}$ in diameter and $5 \mathrm{~mm}$ deep) were removed from each agar dish and fresh bacteria suspension was then uniformly spread on each cup. At this point, each of the cups was spotted three times with test solution at concentration of 50, 100 and 200 $\mu \mathrm{g} / \mathrm{cm}^{3}$ in dimethyl sulphoxide (DMSO). After incubating the plates at $37^{\circ} \mathrm{C}$ overnight, the diameter of the zone of inhibition of the bacteria growth was then recorded.

A 5\% phenol solution was used as a positive control and DMSO as solvent control each time the experiments were performed.

\section{RESULTS AND DISCUSSION}

The composition of the solutions used for the equilibrium studies are shown in Table $1 . \mathrm{HNO}_{3}$ $\left(0.01 \mathrm{~mol} \mathrm{dm}^{-3}\right)$ was used in the preparation of the back ground electrolyte solution to suppress the hydrolysis of iron(III). At $\mathrm{pH}$ values above 3.5, precipitation (accompanied by the formation of some hydrolysis products) occurred, rendering such solution unsuitable for absorbance measurements.

Table 1: Composition of Solution used for Equilibrium Studies $\left(\mathrm{Fe}^{3+} / \mathrm{INHA}\right)$

\begin{tabular}{cll}
\hline$\left[\mathbf{F e}^{\mathbf{3 +}}\right]$ & {$[\mathbf{I N H A}]$} & $\mathbf{p H}$ \\
\hline 0.005 & 0.0005 & 2.12 \\
0.005 & 0.0005 & 2.23 \\
0.005 & 0.0005 & 1.45 \\
0.005 & 0.001 & 2.77 \\
0.005 & 0.001 & 3.48 \\
0.005 & 0.00125 & 1.36 \\
0.005 & 0.00125 & 2.19 \\
0.005 & 0.00125 & 2.59 \\
0.005 & 0.0015 & 2.04 \\
0.005 & 0.0015 & 2.86 \\
\hline
\end{tabular}

\begin{tabular}{lll}
\hline 0.005 & 0.0015 & 2.92 \\
0.005 & 0.002 & 1.57 \\
0.005 & 0.002 & 2.30 \\
0.005 & 0.0025 & 1.97 \\
0.005 & 0.0025 & 3.02 \\
\hline
\end{tabular}

The spectral data were digitized at $5 \mathrm{~nm}$ intervals and processed by the computer program SQUAD (Biruset al., 1998). The program calculates the composition, stability constants and molar absorptivities of the complexes by minimizing the sum of the squared residuals, $S$, defined as:

$\mathrm{S}=\sum\left(\mathrm{A}_{\mathrm{obs}}-\mathrm{A}_{\text {calcd }}\right)^{2}$

Where $A_{o b s}$ is measured absorbance and $A_{\text {calcd. }}$ is the absorbance calculated by the program from the equation:

$\mathrm{A}_{\text {calcd }}=\sum \mathrm{Bp}, \mathrm{q}, \mathrm{r}[\mathrm{Fe}]^{\mathrm{p}}[\mathrm{H}] \mathrm{q}[\mathrm{L}]^{\mathrm{r}} \quad \mathrm{Ep}_{1} \mathrm{q}_{1}{ }^{\mathrm{r}}$.

The results of the calculations indicated the formation of $\left[\mathrm{Fe}(\mathrm{INHA}]_{3} \cdot 2 \mathrm{H}_{2} \mathrm{O}\right.$ with a stability constant $\log \mathrm{B}_{3}+34.22+0.06$ where $\mathrm{B}_{3}=$ $\left[\mathrm{FeL}_{3}\right] /\left[\mathrm{Fe}^{3+}\right][\mathrm{L}] 3$.

Several equilibrium models were tried but it was only with $\mathrm{ML}_{3}$ that convergence was achieved. Models in which $\mathrm{ML}^{2+}$ and $\mathrm{ML}^{+}$included failed to achieve convergence due to persistently high standard derivation of the constant, this indicates that the species are not present in any significant concentration at equilibrium (Cruckshank, 1965). The standard deviation in the absorbance data is $3.7 \times 10^{-3}$ for $\left[\mathrm{Fe}(\mathrm{INHA})_{3} \cdot 2 \mathrm{H}_{2} \mathrm{O}\right.$ ]. This statistical parameter, together with the standard deviation in the refined constant, indicates the consistency of data (Braibanti and Bruschi, 1977 and Legget and Legget, 1985).

Analyses of the calculated spectrum of the complex shows a $\mathrm{pH}$ dependence of the absorption maxima. $\mathrm{Fe}(\mathrm{INHA})_{3} \cdot 2 \mathrm{H}_{2} \mathrm{O}$ exhibits an absorption maxima centered at about 500nm $(\Sigma=$ 614 ) for solution of $\mathrm{pH}$ less than 2; this is shift to $470 \mathrm{~nm}(\Sigma=631)$ for $\mathrm{pH}>2$. This $\mathrm{pH}$ dependence is due to the shift of equilibrium. 


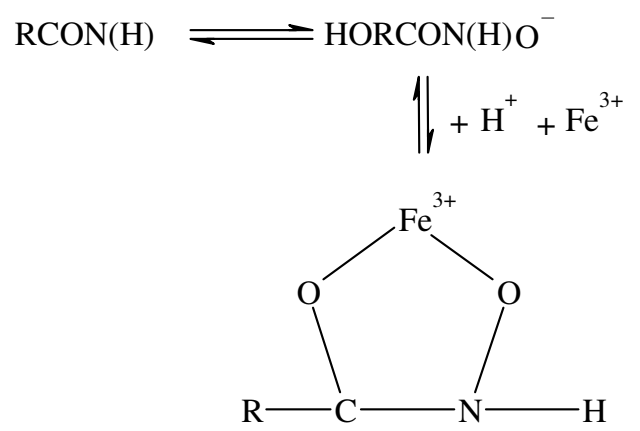

A shift to the right results from deprotonation of the ligand as basicity increases.

The ligand shows comparable affinity for iron(III) ion. The low stability constant of $\left[\mathrm{Fe}(\mathrm{INHA})_{3}\right] \cdot 2 \mathrm{H}_{2} \mathrm{O}$ despite the high pka valve of INHA may be due to steric effects of its large ring (Nwabueze,1996).

The pka value for the ligand is $8.68+0.05$. The high basicity of the ligand may be ascribed to the positive inductive effect of the larger pyridine ring attached to it. Figure 1 shows the absorption spectra of solutions containing a constant metal but variable ligand molar concentration of the INHA system; while figure 2 shows the graphical matrix rank analysis for the absorbance data generated from similar solutions for the INHA system. In this regard, the two systems show similar behaviour. The absence of an isosbestic point and the shape of the graph is typical of systems containing only one complex species (Legget and Bryde, 1975). The composition of the complex in solution was determined as a 1:3 $\mathrm{M}: \mathrm{L}$ species by Job's plot as shown in figure 3 (Hartley et al., 1980).

The analytical data and some physico-chemical properties of the ligand and its isolated complex are shown in Table 2.

Table 2: Analytical data and some physicochemical properties of the ligand and its Isolated Complex.

\begin{tabular}{lcc}
\hline & INHA & $\begin{array}{c}\text { Compound } \\
\mathrm{Fe}(\mathrm{INHA})_{3} \cdot 2 \mathrm{H}_{2} \mathrm{O}\end{array}$ \\
Formula & $\mathrm{C}_{6} \mathrm{H}_{7}$ & $\mathrm{C}_{18} \mathrm{H}_{22} \mathrm{~N}_{4} \mathrm{O}_{8} \mathrm{Fe}$ \\
& $\mathrm{N}_{2} \mathrm{O}_{2}$ & \\
FW & 139 & \\
& & 477.90 \\
\hline
\end{tabular}

\begin{tabular}{lcc}
\hline Mp/Dec ${ }^{0} \mathbf{C}$ & 96 & 210 \\
Colour & Cream & Dark red \\
Neff (B.M) & - & 5.85 \\
298K & & 410 \\
$\lambda_{\text {Max }} \mathbf{n m}$ & - & $11.07(11.66)$ \\
$\begin{array}{l}\text { Found } \\
\text { (calcd) (\%) }\end{array}$ & - & \\
Assignment & - & ${ }^{6} \mathrm{~A}_{1 \mathrm{~g}} \longrightarrow{ }^{4} \mathrm{~A}_{1 \mathrm{~g}},{ }^{4} \mathrm{E}_{\mathrm{g}}$
\end{tabular}

$\mathrm{M}=$ metal, $\mathrm{FW}=$ Formula weight, $\mathrm{MP} / \mathrm{Dec}=$ Melting Point/Decomposition, B.M = Bohr Magneton. $\lambda_{\text {Max }}=$ Wavelenght

The visible Spectrum of the complex shows a broad band centered at about $410 \mathrm{~nm}$ following similar earlier observation and has been assigned to ${ }^{6} \mathrm{~A}_{1 \mathrm{~g}} \longrightarrow{ }^{4} \mathrm{~A}_{1 \mathrm{~g}},{ }^{4} \mathrm{E}_{\mathrm{g}}$ transition (Nicholls, 1974). The position of the band together with the observed magnetic moments is consistent with an octahedrally-coordinated high spin iron(III) complex (Nicholls, 1974).

The i.r bands in the ligand and its position in the corresponding complex is reported in Table 3. The spectrum of the ligand shows a band at $3422.59 \mathrm{~cm}^{-1}$ and a broad band at $1605.01 \mathrm{~cm}^{-1}$, which cure assigned to $v(\mathrm{NH})$ and $v(\mathrm{C}=\mathrm{O})$ vibrations respectively. The position of the bands and the broadening of the $v(\mathrm{C}=\mathrm{O})$ band indicates hydrogen bonding in the molecules. In the complex, the $\mathrm{v}(\mathrm{C}=\mathrm{O})$ band is lowered to about $3.24 \mathrm{~cm}^{-1}$ while the $\mathrm{v}(\mathrm{C}-\mathrm{N})$ vibration observed at $1125.95 \mathrm{~cm}^{-1}$ in the ligand is shifted to $1157.98 \mathrm{~cm}^{-}$ ${ }^{1}$ in the complex. These observations indicated $\mathrm{N}$ - bonding mode.

Table 3: Diagnostic I.R Data for the complex

\begin{tabular}{lcc}
\hline I.R Data & INHA & $\mathrm{Fe}(\mathrm{INHA})_{3} .2 \mathrm{H}_{2} \mathrm{O}$ \\
$\mathbf{v}(\mathbf{N H}) \mathbf{c m}^{-\mathbf{1}}$ & 3422.59 & 3382.12 \\
$\Delta \mathbf{v}(\mathbf{N H}) \mathbf{c m}^{-1}$ & - & -40.47 \\
$\mathbf{v}(\mathbf{C}=\mathbf{O}) \mathbf{c m}^{-1}$ & 1605.01 & 1602.77 \\
$\Delta \mathbf{v}(\mathbf{C}=\mathbf{O}) \mathbf{~ c m}^{-1}$ & - & -3.24 \\
$\mathbf{v}(\mathbf{C N}) \mathbf{c m}^{-1}$ & 1125.95 & 1157.98 \\
$\Delta \mathbf{v}(\mathbf{C N}) \mathbf{c m}^{-1}$ & - & +31.33 \\
\hline
\end{tabular}

INHA = Isonicotinohydroxamic acid

On the basis of the observed physico-chemical properties, the structure (Scheme 1) is proposed for the complex. 


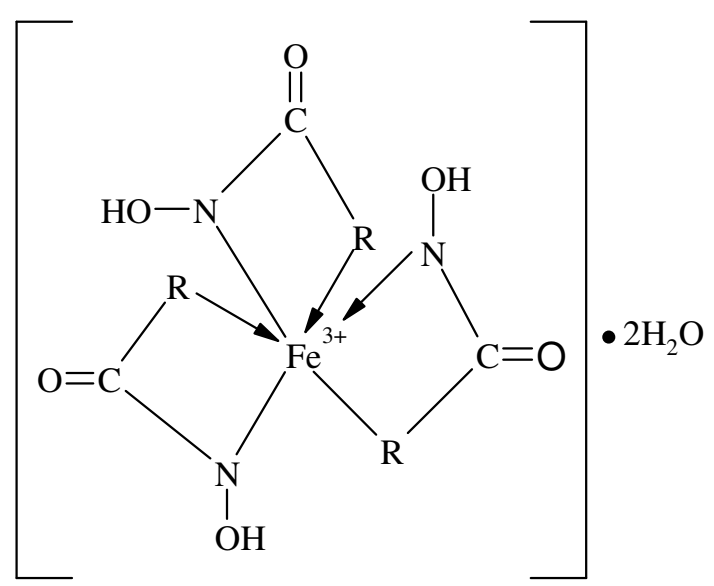

Key: $\mathrm{R}=$ Pyridine.

Scheme 1: Proposed structure having N- bonding mode and is an octahedrally coordinated complex.

The results of the microbial sensitivity test carried out on the ligand and its isolated Fe(III) complex are shown in Tables 4 and 5. It is evident from Table 4 that $\mathrm{Fe}(\mathrm{III})$ complex exhibit moderate activity against $S$. Typhlium, Klebsiela, aureus, E. Coli, $\alpha$-heamolytic strep. and Neisseria.

Table 4: Diameter of Zone of Inhibition

\begin{tabular}{lcc}
\hline Diameter $(\mathrm{mm})$ & Symbol & $\begin{array}{c}\text { Comment on } \\
\text { Activity }\end{array}$ \\
\hline $12-15$ & + & Insignificant \\
$16-20$ & ++ & Minimum \\
$21-25$ & +++ & Moderate \\
$26-35$ & ++++ & Maximum \\
\hline
\end{tabular}

Table 5: Microbial Sensitivity Test for the Ligand and its isolated Fe(III) Complex.

\begin{tabular}{lcc}
\hline Bacteria & INHA & $\mathrm{Fe}(\mathrm{INHA})_{3} 2 \mathrm{H}_{2} \mathrm{O}$ \\
\hline Staph. Aureus & ++ & +++ \\
S. Typhylium & ++ & +++ \\
E. Coli & ++ & ++++ \\
Klebsiella & ++ & +++ \\
a-hemolytic Strep & ++ & ++++ \\
Neisseria & ++ & ++++ \\
Pseudo-cnonias & ++ & +++ \\
Coryne-bacteria & ++ & +++ \\
& & \\
\hline
\end{tabular}

Pseudomonas and corynebacteria, while maximum activity was exhibited against $S$.

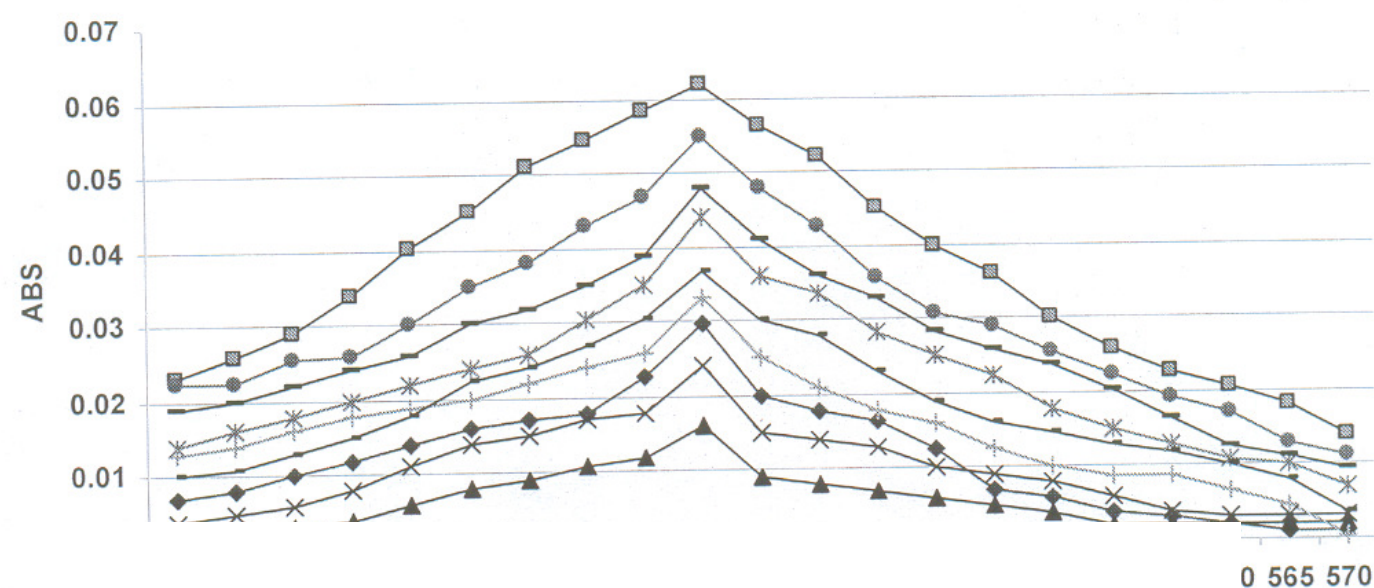

$\mathrm{nm}$

Fell

FIG.1: Is os bestic point search for Fem NHA system

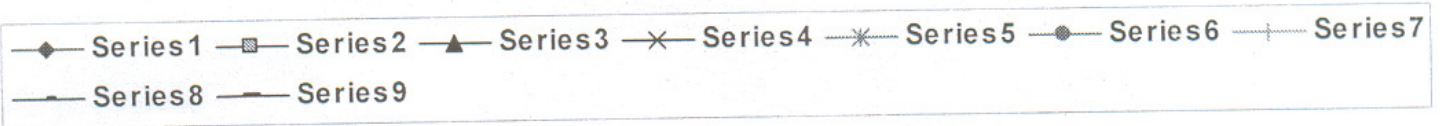




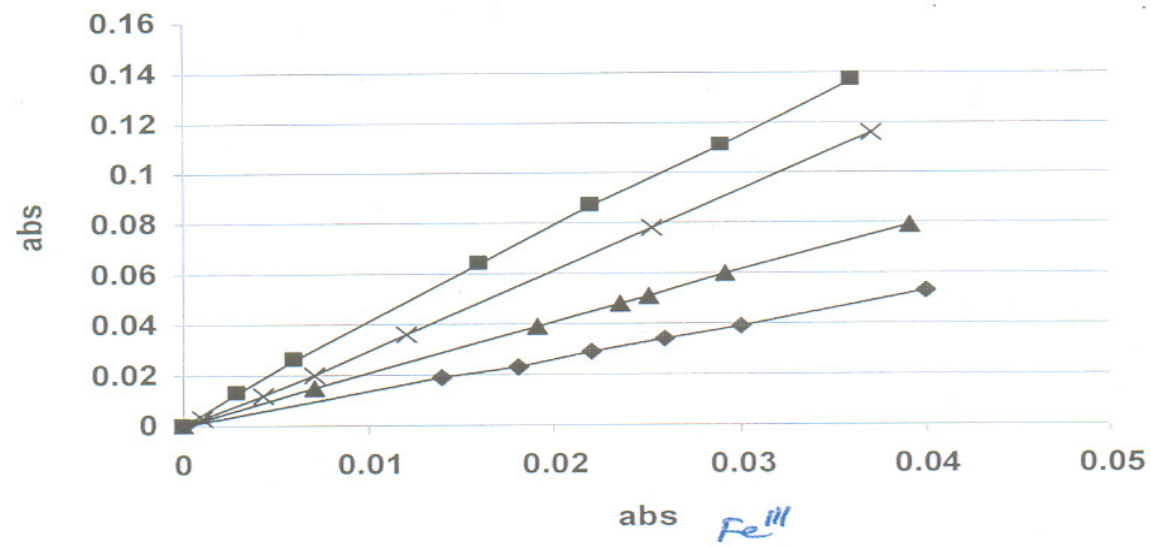

Fig 2: Graphical rank Matrix analys is for Fe"-NHA system (one specie test)

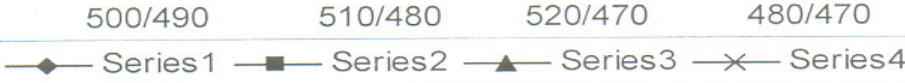

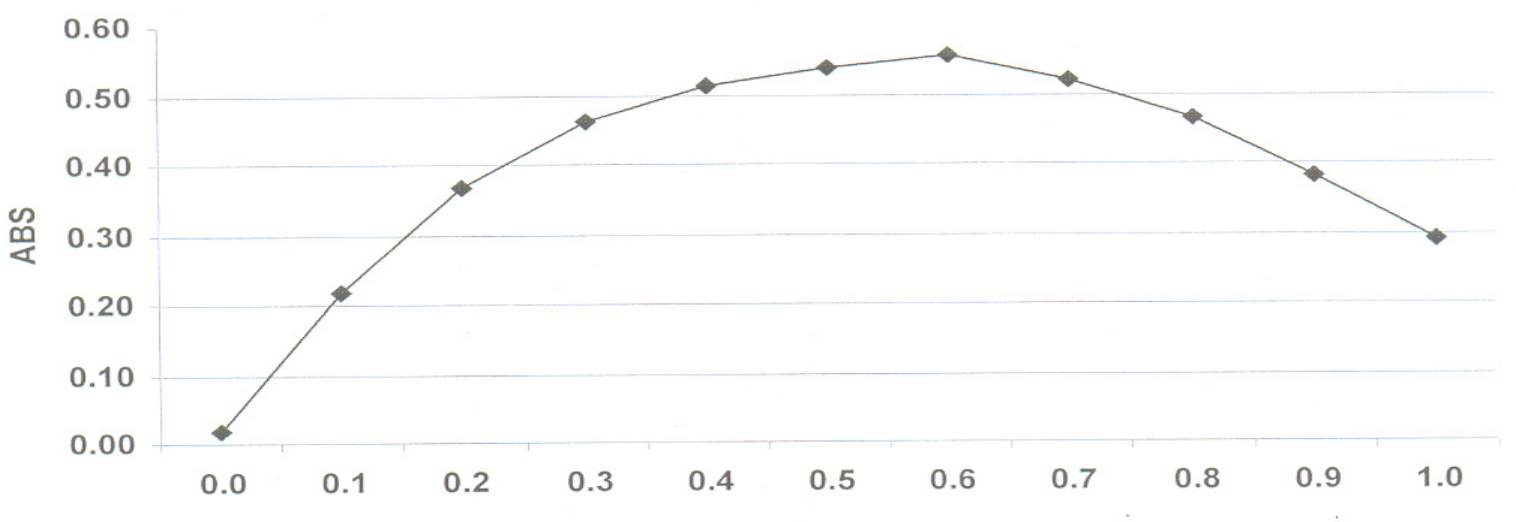

Mole fraction of ligand

Fig 3: Continuous variations (Job's plot) method for - - II a In ......... 


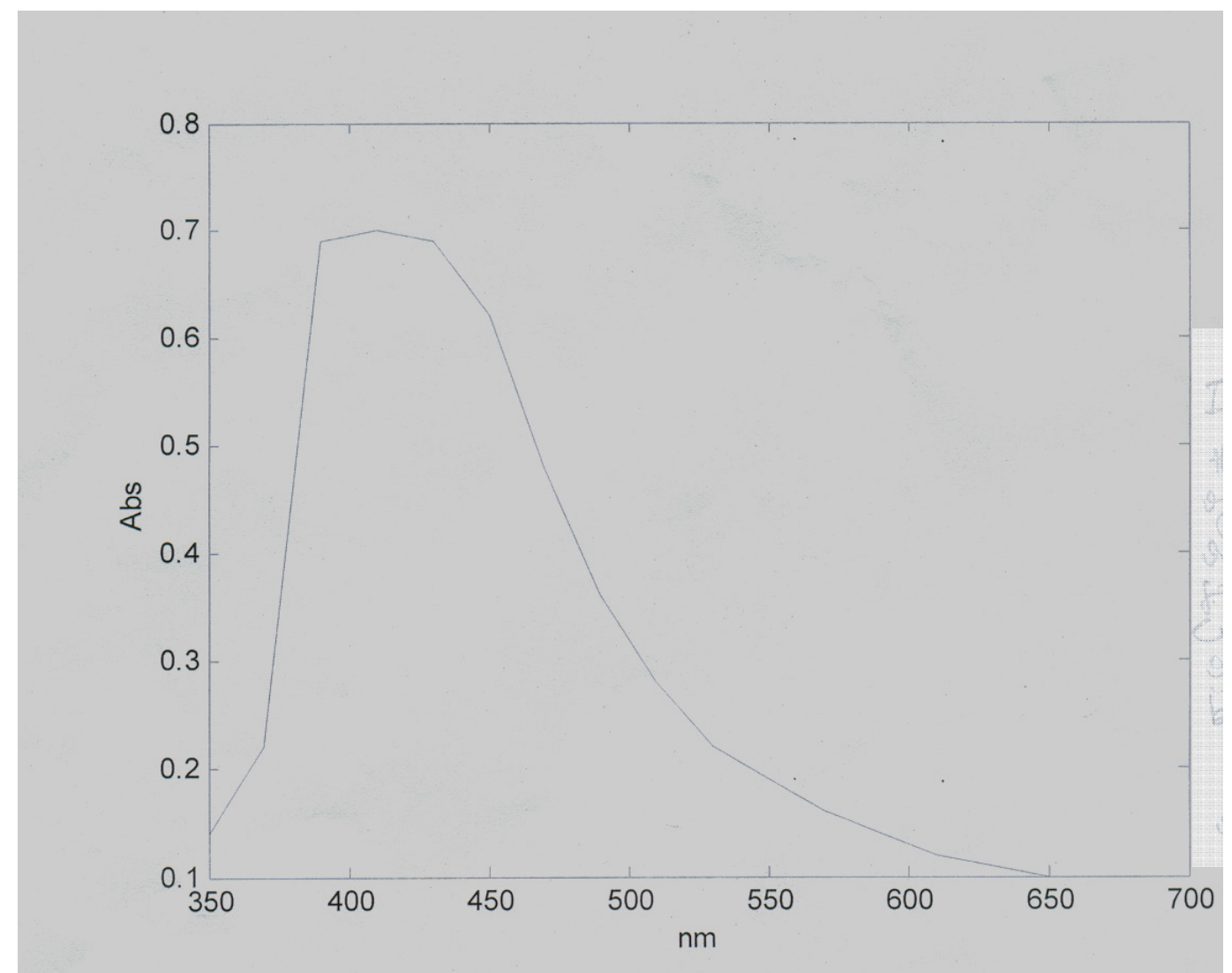

\section{REFERENCES}

Aliyu, A.O. and Nwabueze, J.N. (2008). Complex of nickel(II) with isonicotinohydroxamic acid. Inter. $J$. Physical Sci. 3(1): 081-021.

Albert, A. and Sergent, E.P. (1971). The determination of ionization constants, $2^{\text {nd }}$ edition, Charpman and Hall, London pp. 44.

Bates, G.W. and Saltman, P. (1972). In: Williams D.R. (ed.) An Introduction to Bioinorganic Chemistry, Thomas, Illinois, P 145.

Nigovic, B., Kujundzic, N. and Sankonic, K. (2002). Complex formation between transition metals and 2-pyrrolidone-5hydroxamic acid. Acta. Chem. Sloc. 49(3): $525-535$.

Braibanti A and. Bruschi, C (1977), Am Chim,67, 471.

Brown D.A, Dervilla Mckeith and W.K. Glass (1979) Morganica Chimica Acta 35, 5.

Celine J. Marmion and Kevin B. Norlan. (2002) $\underline{\text { www.irishscientist }}$
Cruckshank R. (1965) Medical Microbiology Eds Church and Livingston U.K. pp 75-85.

Dobbin P.S. and Hider R.C. (1990) Chem. Britain 26, 565.

Hartley F.R., Burgess C.. and Alcock, R.M.; (1980) Solution quilibra. Ellis Horwood, Sussex P. 33.

Jones L.W. and Scott A.W. (1922). New hydroxamic acids derived from cyclopropane carboxylic acid, isobutyric acid and dibenzyl-acetic acid. A comparative study of the beckmann rearrangement of their derivatives. $J$. Am. Chem. Soc. 44(2): 407 - 423.

Kurzak, B; Kozlowski, H; Garkas, E. (1992).

Hydroxamic and aminohydroxamic acids and their complexes with metal ions. Coord. Chem.

Rev. 114(2): 169 - 200.

Legget D.Jin. Legget D (Ed) (1985), Computational Methods for the determination of stability constants, Plenum, London pp159.

Legget D.J. and Mc.Bryde W.A.E. (1975). General computer program for the computation of stability constants from 
absorbance data. Anal. Chem. 47(7): 1065-1070.

Fernandes, M.C.M.M, Paniago, E.B. and Carvalho, S. (1997). Copper(II) Mixed Ligands Complexes of Hydroxamic Acids with Glycine, Histamine and Histidine. $J$. Braz. Chem. Soc. 8(5): 537 - 548.

Birus, M., Inic, S., Nikola Kujundzic, N. and Nigovic, B. (1998). Complexation of Iron(III) by Cystinedihydroxamic Acid Coratica, Chemica Acta 71(3): 807 - 816.
Nicholls D. (1974). Complexes and First Row Transition Elements, Macmillan, London, pp 89-95.

Nwabueze J.N. (1996). Complexes of iron(III) with cyclopropanecarbo- and cyclohexylacetohydroxamic acids. Transition Met. Chem. 21(3): $258-261$.

Nwabueze J.N and Aliyu A.O (2007)Complexes of oxovanadium IV with some hydroxamic acids. Eur. $J$. Scientific Res. 18(3): 417-426. 